\title{
Edmund Phelps on Productivity Slowdown: Limits to Utilitarian Economics
}

\section{A Comment on "What is Wrong with the West's Economies?" by Edmund Phelps}

\author{
Shanti P. Chakravarty ${ }^{1}$
}

Received: 10 January 2016/Accepted: 21 February 2016/Published online: 23 August 2016

(C) The Author(s) 2016. This article is published with open access at Springerlink.com

\begin{abstract}
Nobel Laureate economist Edmund Phelps blames the increasing marginalisation of a large number of workers in unstimulating jobs on low wages as a contributory factor to productivity slowdown in the West. He blames utilitarian economics because it cannot accommodate the idea of social inclusion. In our view, the problem is best understood as a manifestation of the poverty of the theory of prices governing the allocation of resources.
\end{abstract}

Keywords Science policy · Innovation · Inequality · Information · Uncertainty · Productivity

JEL Classification B59 - D80 - J01 - O31

\section{The Phelps Critique}

In a provocatively-titled essay, Edmund Phelps outlines his disquiet about the evolution of an unjust society in the West where a significant number of citizens are denied the ability to fulfil their "desire to participate in a community in which they can interact and develop". They are not "given the experience of using their minds" even when they are able to find paid employment or when they are protected, as in some countries, from the worst aspects of financial deprivation by the safety net of a Rawlsian welfare state. He goes further in maintaining that far too much monetary rewards accrue to those that manage to debase the political process to gain entrenched

\footnotetext{
1 Quotations from the article by Phelps appearing in New York Review of Books and reprinted in this volume are not referenced by page number in the text. They are simply indicated by quotation marks.
}

Shanti P. Chakravarty

s.p.chakravarty@bangor.ac.uk

1 Bangor Business School, The University, Bangor LL57 2DG, Wales, UK 
property rights, discouraging competition and innovation. Although companies "like Google and Facebook may offer jobs allowing or requiring imagination and creativity, but the whole of Silicon Valley accounts for only 3 percent of national income and a smaller percentage of national employment".

A consequence of the reward structure and the nature of the employment contract is the emergence of an economy where creativity and imagination are seldom encouraged. The accusations are sweeping and, to keep track of the arguments, we shall hang our analysis on a single peg: his concern "about the terms on which each participant contributes to the fruit of the society's economy". In our view, Edmund Phelps' critique of Western capitalism is a critique of utilitarian price theory informing discourse about the allocation of resources in a market economy. The information requirement for efficient prices is onerous, especially when decisions taken in one period have impact on a distant future. Thus there is an inherent inability of the markets to ascertain the potential outcomes of creative activity. This fault is deepened when non-market institutions supporting fundamental research are subjected to spurious market-mimicking cost-benefit analyses. A further development since the last quarter of the twentieth century is that the market price of labour has become divorced from the contribution of labour. Rewards at the top are often based not on output alone but also on the ability to capture the remuneration process which governs the algorithm for assigning output to effort. We shall return to these claims presently.

\section{Reading Phelps}

Many of the ideas discussed by Phelps' contribution in this volume were also raised by him earlier (Phelps 2013). Some of the misgivings about Western economies in general and the US economy in particular have also been expressed by others before him. Rawls had argued that in a just world, only those inequalities should be permitted which will "work out for the advantage" of all (Rawls 1973: 324). The type of inequality that has evolved in recent years, leaving a large swathe of the population economically marginalised and left without opportunities for creative employment, makes us all poorer, according to Phelps, by retarding innovation and suppressing creativity. We shall return to this presently. First let us place Phelps in context, starting with his concern about the power of corporations.

President Dwight Eisenhower, coining the phrase military industrial complex, warned in his farewell address in 1961 about the danger of large corporate interests hijacking government policy for the benefit of the few. In his 1966 Massey lectures entitled "The Moral Ambiguity of America" aired on radio by the Canadian Broadcasting Corporation, a recurring theme of the American social critic Paul Goodman was the deleterious impact on creativity of the power that large organisations wield in the economy, altering the terms of education in a uniform mould: “...when an expanding corporation becomes very grand, it generates an expertise of its own called systems development, applicable to anything...there is no longer any need to demonstrate acquaintance with any particular human function" (Goodman 1968: 261). 
Like Phelps now, Goodman then also lamented that “...our regulatory agencies are wonderfully in agreement with the corporations they regulate" (Goodman 1968: 358). Nothing much has changed. There is a culture of fear amongst civil servant working for regulators. Carmen Segarra, a lawyer, was fired by the New York Federal Reserve, as secretly taped conversations with her superiors indicate, after refusing to tone down a report critical of the conduct of one of the largest finance houses whose senior staff enjoy access to government at the highest level (Younge 2014).

An economy where large rents accrue through the capture of property rights by powerful groups employing lobbyists to influence legislators does not provide incentives for innovation through risk taking in the choice of investment. Phelps gives an example in the automobile industry of attempts to gain monopoly rent with the connivance of government. He might also have mentioned the phenomenon of the corporate executives who find it possible, since the start of financial liberalisation, to divert corporate profits away from investment into share buybacks for personal gain.

Five hundred amongst the highest-paid corporate executives in the United States received $83 \%$ of their remunerations through stock options and awards in the year 2012. "As a result, the very people we rely on to make investments in the productive capabilities that will increase our shared prosperity are instead devoting most of their companies' profits to uses that will increase their own prosperitywith unsurprising results. Even when adjusted for inflation, the compensation of top US executives has doubled or tripled since the first half of the 1990s, when it was already widely viewed as excessive" (Lazonick 2014). A consequence of these developments is the enormous increase in the share of the national income in the hands of the top percentile since the start of liberalisation in the late 1970s (Atkinson 2005; Atkinson et al. 2011).

The US Supreme Court judge Louis Brandeis warned of the adverse consequence for democracy of the emergence of a super-rich class with their financial muscle to control the flow of information in their favour. "We may have democracy, or we may have wealth concentrated in the hands of a few, but we cannot have both" (cited in Ayres and Edlin 2011). Concentration of national income in the top percentile of the population, having declined in the post-war period, started to rise again in Western democracies, and especially in the US and the UK, since the start of economic liberalisation in the late 1970s. The post-liberalisation inequality has another notable characteristic which concerns Phelps: a large fraction of the workforce has been relegated at the bottom of the earnings ladder, condemned to routine work. An economy which relegates a large number of people to employment which does not encourage "using their minds" thus excluding a significant proportion of the citizenry from opportunities for self-fulfilment. Utilitarian economics does not take into account the requirement of the "opportunity to achieve" (Sen 2002: 510) in arriving at its prescriptions for efficiency. The opportunity for expressing creativity, exploring the unknown where the destination is unknown, is essential for the pursuit of self-fulfilment. Capacities "enter into selffulfilment viewed as achieving the best that it is in one to become" (Gewirth 1998: 
63). Thus follows Phelps' assertion that social exclusion is not only unjust but it also stifles creativity and imagination rendering the economy poorer for that.

Phelps is concerned that the rewards of economic activity are determined by competition between organised groups and corporations, and there is little left "in the public purse for low wage workers" (Phelps 2015: 1). He blames utilitarian economic theory because it is focused on aggregate welfare and thus it is "blind to the very concept of inclusion". There is another aspect of the theory that he might also have flagged up as the culprit, the theory of prices. Robert Dorfman, a Nobel Laureate economist, argues that the role of economics is to weigh up options at the margin. If there is no trade-off, there is no economic problem to consider (Keyfitz, 1994: 25). The trade-off between alternatives is measured by their relative price.

In the pristine model of a perfectly competitive efficient market, income received by offering capital and labour, factors of production, to the productive endeavour in an economy is proportional to the contribution of the factor concerned to output at the margin. This proportionality provides legitimacy for income distribution, equating ability to produce with market rewards, that results in such an economy (Nozick 1973). However, this legitimacy is fragile in a real market economy. Wage setting in a real economy focuses on what Phelps Brown (1979: 15) calls the "limitation of personal qualities". The limitation of personal qualities is not the same as the limitation of personal abilities except in the uninteresting case of perfect competition where rewards and contributions to output at the margin equalise. The personal qualities that determine wages also include qualities which enhance the ability to capture the measurement of contribution informing the remuneration process.

Technical assumptions made in the theory of prices in a perfect market about the nature of the choice set on which decisions are made are problematic. For example, all economic agents are assumed to be privy to all relevant information about choices available and every consequence of choices that are made. This assumption is especially difficult to justify in explaining creative endeavour where the outcome is not predictable. There are further problems with this valuation model in determining the allocation of resources for basic research.

The valuation model in utilitarian economics can accommodate human effort only as a commodity. In this model, there is "no conception of human agency, only responses to wages, interest rates, and wealth". Thus policy based on this model cannot address the problem that a large number of workers lack "access to jobs offering work and pay that provide self-respect". Nor can any policy based on this model provide the appropriate environment for fundamental research.

Utilitarian economists have long been aware of the shortcomings to which Phelps draws attention notwithstanding the shyness of textbook writers and policymakers to confront these shortcomings. For example, Hahn (1982) observed many years ago that the utility derived from choice is policy dependent. Choices made by an individual are not purely mechanical decisions in response to incentives as postulated in standard economics. Suppose that I sleep N hours a day as my utility maximising choice in the allocation of time between sleep and non-sleep. I make that choice of my own volition. If now a law is passed which requires me to do what I would have done otherwise, sleep $\mathrm{N}$ hours a day, I might suffer a decline in the 
feeling of well-being from making that choice. Some people might even "be relieved because their choice was confirmed officially and became a social norm" (Toedter 2016). The choice set is conceptually difficult to articulate with absolute precision. Undergraduate textbooks in economics may be reticent about engaging with the impact of the ambiguity of choice on price theory, especially in the valuation of human labour. But the above critique of rational choice utilitarian economics is not new. It may even be argued that Keynesian macroeconomics is a response to this limitation of rational choice theory of micro-economics (Lawson 1981; Chakravarty and Mackay 1999).

Phelps places the shortcomings of economics into sharper focus by drawing attention to new forms of labour contracts which have gained currency in recent years. "A distinctive technical quality of labour contracts of this sort is the grouping of tasks into modules that can be detached from particular contexts and be assigned to people with small or no acquaintance with specific organizations" (Kallinikos 2003: 598). Changes in the labour market and globalisation in the production process happen to have coincided. There is now, Phelps claims, the "near disappearance of imaginative and creative activity". He argues that, especially in Western Europe, changes in the labour markets have reduced "indigenous innovation, contracted investment activity, and depressed the demand for labour".

When work is modularised into small mechanical components, labour loses bargaining power over wages. These economic developments have resulted in the exclusion of significant numbers in society from the benefits of economic growth by dragging down both "employment and wage rates at the low end". Phelps identifies the culprit: "This failing in the West's economies is also a failing of economics". Let us consider the reason.

Economic theory makes an assumption which is particularly difficult in devising rewards for creative work. It is assumed that "work on the margin-that is, the last increment of work performed-is unpleasant (italics added) and only performed for the sake of the income it yields" (Scitovsky 1976: 91). This is not how creative people view their endeavour.

Philosophers and sociologists and heterodox economists have explored the limitations of mainstream economics, and it would be a gain if Phelps' analysis puts pressure on economists to acknowledge the poverty of received price theory in guiding research policy. Market economies have made great strides, but the recognition of this fact does not preclude the observation that there is need to engage with the idea of human agency. Also, market efficiency conditions do not obtain when there is asymmetric information between buyers and sellers. Treatment of education and healthcare as commodities is questionable and failing to recognise the asymmetric information between providers and beneficiaries is simply wrong. We have seen in the financial sector the folly of relying on the markets in decisions when there are great unknowns. Risk taking in the choice of topics in fundamental research cannot be conceded either to the market or to market-mimicking shadow prices.

Economists would need help from accountants and sociologists who better understand social relations that mediate transactions between organisations and between individuals and organisations to engage with the problem of exclusion of 
large segments of the population in modern economies, and to address the need for providing space for creativity. The sociologist Richard Sennett has been chronicling the corrosive influence on self-respect of the modern labour contract (Sennett 2000).

\section{Imagination, Creativity and Innovation}

Phelps gives examples of technological innovations in earlier centuries, for example, Singer's sewing machine and Stephenson's engine. These are examples of product development. His critique of economics is even more apposite in the case of scientific discovery where the usefulness of that discovery in the applied work of fabricating new devices may only become apparent years after the discovery. This is fundamental research, and price theory in economics provide little guide to its valuation.

The reorientation of the education system "in order to fuel the human desire to conceive the new" desired by Phelps cannot occur if all knowledge is viewed as a potentially marketable commodity. The economic models that are the subject of Phelps' critique can only deal in commodities whose characteristics are known, making possible market transactions. Information has properties that make it an inappropriate item for the market (Arrow 1962). The financial crunch is a telling example of the reliance on markets to get around the information problem in lending by devising financial derivatives, many of which are demonstrably inappropriate tools for mitigating risk.

At a function at the London School of Economics in 2008, the British Queen surprised the audience by gently posing an explosive question about the failure of the mainstream academic profession to anticipate the credit crunch. An answer was drafted under the auspices of the British Academy (Besley and Henessy 2009). They lamented that there was an unwillingness to engage with the evidence of "imbalances in financial markets" in the profession:

"...most were convinced that banks knew what they were doing. They believed that the financial wizards had found new and clever ways of managing risks. Indeed, some claimed to have so dispersed them through an array of novel financial instruments that they had virtually removed them. It is difficult to recall a greater example of wishful thinking combined with hubris" (Besley and Henessy 2009).

Resort to utilitarian valuation models of market economics in formulating science policy is just as problematic. Markets cannot accommodate curiosity driven research. Application of a crude economic model of human behaviour to science policy has potentially stifling effect on progress in basic research underpinning technological innovation in the future. What motivates scientists is poorly captured in the Pavlovian approach to monetary incentives in economics (Porter 1974-1975). Consider O'Neill for an explanation (1990: 601):

"If one also accepts Popper's claim that the progress of human knowledge is in principle unpredictable-if we could predict future knowledge, we would 
already have it - then it follows that since human invention relies on the progress of knowledge, and wants and needs are created by human invention, then human wants and needs are also in principle unpredictable".

Charles Townes shared the 1964 Nobel Prize in Physics with Nicolay Basov and Aleksandr Prokhorov for their work leading to the development of lasers, light amplification through stimulated emission and radiation, but the idea of stimulated emission amplifying light is based on work published half a century earlier in 1917 by Einstein (Townes 1964: 59). When these Russian and American scientists were working independently in the 1950 s on "stimulated emission for microwave emission" (Lengyel 1966: 1), they did not know that their curiosity would lead to the construction of lasers. When a laser was first built in 1960 by Theodore Harold Maiman, he did not know that many different types of lasers would follow which would contribute to massive advances in medical, manufacturing and communications technologies later in the century. Lord George Porter, a Nobel Laureate in Chemistry, gives the example of Michael Faraday who discovered that electricity is generated when a wire is agitated in a magnetic field. This discovery was the result of curiosity. Faraday was not trying to solve any industrial problem. He did not know that the impact of his discovery on the engineering of electricity generation would transform industry in Britain many decades afterwards. When asked by the Prime Minister of the day, Robert Peel, about the usefulness of his discovery of magnetic induction, Faraday replied: "I know not, Sir, but I'll wager one day you'll tax it" (Porter 1974-1975: 1).

The decline in creativity lamented by Phelps may be due to an increasing attempt to fit creative work into a mould that can be quickly measured and priced for cost benefit analysis to entice industrial participation in basic research. The American educational theorist Thorstein Veblen (1904) highlighted the problem of locating basic research in private industry. All inventions may not be profitable within the accounting time span of profit seeking producers. In a lecture in defence of the public funding of curiosity-driven research, the Nobel Laureate chemist Sir Hans Kornberg pointed out that industry contributed only $4 \%$ of the total expenditure on basic research in the US in 1981 (Kornberg 1985: 13). The corresponding percentage contribution by industry to fundamental research in Britain might be even smaller. Monetary incentives based on a price system which cannot by construction impound knowledge of the future that is unknown can hardly be appropriate for encouraging advances in science.

Non-market institutions in the sciences, for example the Royal Institution where Faraday played with magnets, emerged to teach us things that later, often much later, would underpin product innovation in industrial laboratories and manufacturing facilities. How such institutions evolved is a matter that is outside the remit of utilitarian economics. This evidence is uncomfortable for those that view the role of economics as a task of providing precise answers to all problems, even those that are imprecisely understood, of resource allocation.

The point remains that non-market institutions did emerge in market economies to provide space for creativity. We do not know whether they were the best for the purpose, but we do know that forcing them in recent years to adopt exercises in 
utilitarian cost benefit analysis, as in the UK, have been detrimental to creative work, discouraging risk taking in the choice of topics to explore (Head 2011). These utilitarian exercises entail the calculation of shadow prices spuriously mimicking markets that do not exist because they cannot exist, except in the bureaucrat's imagination, due to information constraint. Whether the decline in creativity in France is greater, as Phelps claims, is difficult to judge without further evidence because there is a conceptual problem in making these international comparisons. Original ideas developed and articulated in a language other than English or reported in non-mainstream outlets, often because the ideas are new, can get discounted in the construction of league tables (Kolm 1988). The point remains that the corrosive impact on creativity of bureaucratic assessment of research output determining the funding of universities, as in the UK, lies in shifting "the balance of power in British universities from academics to managers" (Head 2011).

\section{Summing Up}

In a claim not untypical of textbooks in microeconomics, Nicholson suggests that economics is "traditionally defined as the study of the allocation of scarce resources among competing end uses" (Nicholson 1995: 3). The allocation exercise requires a theory of prices.

Phelps' answer to his question "What Is Wrong with the West's Economies", is that the fault lies in the theory informing prices used in the valuation of work. The choice set for resource allocation in this static theory is specified on the claim of perfect knowledge of human needs and wants. This claim assumes that the consequence of the pursuit of knowledge can be predicted and priced with precision. It assumes that creative effort can be encouraged by a Pavlovian model of rewards based on the above prices. That assumption cannot hold in modelling a dynamic economy where creativity flourishes and innovation becomes the norm. Such an economy makes room for creative pursuit driven by curiosity. What we might come to know in our pursuit of knowledge we cannot predict; otherwise it would already be known. The predictive uncertainty cannot be transformed into a measurable risk about potential use of the scientific project because "at any point in time, we are ignorant about the full range of future human needs and wants” (O’Neill 1990: 602).

Open Access This article is distributed under the terms of the Creative Commons Attribution 4.0 International License (http://creativecommons.org/licenses/by/4.0/), which permits unrestricted use, distribution, and reproduction in any medium, provided you give appropriate credit to the original author(s) and the source, provide a link to the Creative Commons license, and indicate if changes were made.

\section{References}

Arrow, K. (1962). Economic Welfare and the Allocation of Resources for Invention. In: National Bureau of Econommic Research, the rate and direction of inventive activity: econnomic and social factors. Princeton, N.J.: Princeton University Press. 
Atkinson, Anthony B. (2005). Top incomes in the UK over the 20th century. Journal of Royal Statistical Society A, 168(2), 325-343.

Atkinson, Anthony B., Piketty, Thomas, \& Saez, Emmanuel. (2011). Top Incomes in the Long Run of History. Journal of Economic Literature, 49(1), 3-71. http://www.aeaweb.org/articles.php?doi=10. 1257/jel.49.1.3.

Ayres, Ian \& Edlin, Aaron S. (2011). Don't tax the rich: tax inequality itself. New York Times.

Besley, Tim \& Hennessy, Peter. (2009). Letter to the queen. http://www.britac.ac.uk/events/archive/ forum-economy.cfm. (downloaded 09-01-2016).

Chakravarty, S. P., \& Mackay, R. R. (1999). Revolution and counter-revolution: two views of unemployment. Cambridge Journal of Economics, 25(3), 337-351.

Gewirth, Alan. (1998). Self-fulfilment. Princeton: Princeton University Press.

Goodman, P. (1968). Growing Up Absurd. London: Sphere Books.

Hahn, Frank. (1982). On some difficulties of a utilitarian economist. In Amartya Sen \& Bernard Williams (Eds.), Utilitarianism and beyond. Cambridge: Cambridge University Press.

Head, Simon. (2011). The grim threat to British universities. New York Review of Books.

Kallinikos, Jannis. (2003). Work, human agency and organizational forms: an anatomy of fragmentation. Organizational Studies, 24(4), 595-618.

Keyfitz, Nathan. (1994). Demographic discord. The Sciences, 34(5), 25.

Kolm, Serge-Christophe. (1988). Economics in Europe and in the US. European Economic Review, 32(1), 207-212.

Kornberg, Sir Hans. (1985). Remaining curious. New Scientist 107 (1471).

Lawson, Tony. (1981). Keynesian model building and the rational expectations critique. Cambridge Journal of Economics, 5(4), 311-326.

Lazonick, William. (2014). Profits without prosperity. Harvard Business Review.

Lengyel, Bela A. (1966). Introduction to laser physics. New York: John Wiley and Sons Inc.

Nicholson, Walter. (1995). Microeconomic theory (6th ed.). London: Dryden Press.

Nozick, Robert. (1973). Distributive justice. Philosophy and Public Affairs, 3(1), 45-126.

O'Neill, John. (1990). Property in science and the market. The Monist, 73(4), 601-620.

Phelps Brown, Henry. (1979). The inequality of pay. Oxford: Oxford University Press.

Phelps, Edmund. (2013). Mass flourishing: how grassroots innovation created jobs. Princeton: Princeton University Press.

Phelps, Edmund. (2015). What is wrong with the west's economics. New York Review of Books, August 13 (republished in this issue).

Porter, G. (1974-1975). The relevance of science. Engineering and Science (December'74-January'75) pdf copy downloaded 15 Dec 2015. www.core.ac.u/k/display/10705045.

Rawls, John. (1973). Distributive justice. In Edmund Phelps (ed) Economic justice. Harmondsworth: Penguin, pp 319-362.

Scitovsky, Tibor. (1976). The joyless economy. London: Oxford University Press.

Sen, Amartya. (2002). Rationality and freedom. Cambridge: Harvard University Press.

Sennett, Richard. (2000). The corrosion of character. New York: W. W. Norton.

Toedter, Karl-Heinz. (2016). Private communication.

Townes, Charles H. (1964). Nobel lecture: production of coherent radiation by atoms and molecules. Nobel Media AB 2014 Accessed 05 April 2016. http://www.nobelprize.org/nobel_prizes/physics/ laureates/1964/townes-lecture.html.

Younge, G. (2014). Carmen segarra: The whistleblower of wall street, The Guardian 05 October. http:// www.theguardian.com/commentisfree/2014/oct/05/carmen-segarrawhistleblower-wall-street-federalreserve. Accessed 29 Dec 2015. 